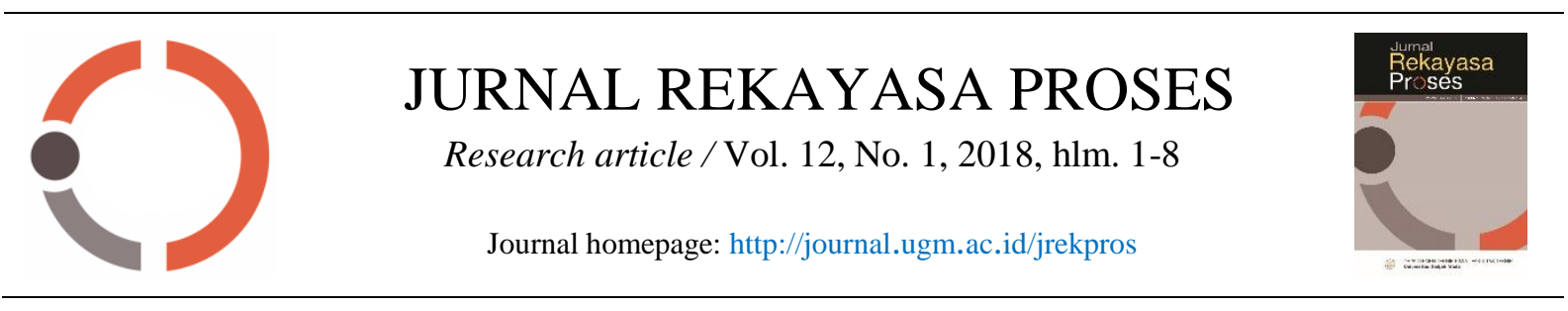

\title{
Pengaruh Steam Pretreatment terhadap Degradasi Selulosa dan Limonen pada Limbah Jeruk dalam Produksi Biohidrogen
}

\author{
Gita Khaerunnisa*, Sarto, Sutijan dan Siti Syamsiah \\ Departemen Teknik Kimia, Fakultas Teknik, Universitas Gadjah Mada \\ Jl Grafika No. 2 Kampus UGM, Yogyakarta, 55281 \\ *Alamat korespondensi: gita.khaerunnisa@mail.ugm.ac.id; khaerunnisa.gita@gmail.com
}

(Submisi:11 Desember 2017; Revisi:18 April 2018; Penerimaan:26 April 2018)

\section{A B S T RACT}

This research presents the influence of steam pretreatment to orange waste and its effect on the production of biohydrogen. The steam pretreatments with various times of 2, 4, and 6 hours were applied to the samples. After the pretreatment, the samples were fermented for seven days, and the contents of cellulose, limonene, volatile fatty acid (VFA), and hydrogen were assessed on the days of 1, 2, 3, 5 and 7. Kinetic parameters of hydrogen production were evaluated using the modified Gompertz's equation. The result of this research showed that the steam pretreatment significantly reduced the cellulose and limonene compounds. The content of cellulose in the substrate after 2, 4 and 6 hours pretreatment were 37.08\%; 36.63\%; and 15.95\%, respectively. Moreover, the content of limonene after pretreatment of 2, 4, and 6 hours were $57.44 \mathrm{ppm} ; 38.80 \mathrm{ppm}$; and $36.11 \mathrm{ppm}$, respectively. Analysis of kinetic parameters of production of hydrogen showed that the maximum productions of hydrogen $\left(H_{\text {max }}\right)$ in the samples after pretreatment of 2, 4, and 6 hours were $11.492 \mathrm{~mL}$; $52.612 \mathrm{~mL} ; 22.345 \mathrm{~mL}$, respectively. The maximum production rates $(\mathrm{Rm})$ at specified pretreatment time (2, 4, and 6 hours) were $9.888 \mathrm{~mL} \mathrm{H}_{2} /$ hour; $10.008 \mathrm{~mL} \mathrm{H}_{2}$ /hour; $12.982 \mathrm{~mL} \mathrm{H}_{2} /$ hour and the lag phases were 49.689 hours; 24.742 hours; and 24.885 hours. The study elucidated that applying pretreatment for 4 hours gives the optimum condition for hydrogen production.

Keywords: orange waste, hydrogen, limonene, cellulose, steam pretreatment

\section{A B S T R A K}

Penelitian ini mempelajari pengaruh steam pretreatment terhadap limonen dan selulosa yang terkandung pada limbah jeruk, dengan mengevaluasi dampaknya terhadap produksi biohidrogen. Steam pretreatment dilakukan dalam 3 variasi waktu, yaitu 2, 4 dan 6 jam. Kemudian proses fermentasi dijalankan selama 7 hari dengan pengambilan sampel dilakukan pada hari ke 1, 2, 3, 5 dan 7. Hasil dari penelitian ini menunjukkan bahwa steam distillation yang dilakukan untuk pretreatment pada substrat jeruk berpengaruh terhadap kondisi substrat, yaitu mengurangi kadar selulosa dan limonen. Kadar selulosa pada substrat setelah pretreatment 2 jam adalah 37,08\%; 4 jam 36,63\%; dan 6 jam 15,95\%. Sementara kadar limonen setelah pretreatment 2, 4 dan 6 jam berturut-turut 57,44 ppm; $38,80 \mathrm{ppm}$; dan 36,11 ppm. Konstanta kinetika produksi hidrogen pada sampel dengan pretreatment 2, 4 dan 6 jam yang diperoleh dengan persamaan Gompertz termodifikasi adalah potensi produksi hidrogen $\left(H_{\text {maks }}\right) 11,492 \mathrm{~mL} ; 52,612 \mathrm{~mL} ; 22,345 \mathrm{~mL}$, laju produksi maksimum $\left(R_{m}\right) 9,888 \mathrm{~mL} \mathrm{H} /$ jam; $10,008 \mathrm{~mL} \mathrm{H} / \mathrm{jam} ; 12,982 \mathrm{~mL} \mathrm{H}_{2} / \mathrm{jam}$ serta waktu adaptasi 49,$689 ; 24,742$; dan 24,885 jam. Perlakuan pretreatment pada sampel selama 4 jam menghasilkan produk paling optimal.

Kata kunci: sampah buah jeruk, hidrogen, limonen, selulosa, steam pretreatment 


\section{Pendahuluan}

Produksi hidrogen saat ini banyak dikembangkan sebagai alternatif energi bersih, karena mempunyai yield energi yang tinggi (122 $\mathrm{kJ} / \mathrm{g}$ ), non polutif dan dapat diperbarui (Han dkk., 2012). Penggunaan biomassa berupa limbah pertanian dalam produksi biohidrogen maupun bioenergi lain mempunyai prospek yang menjanjikan, karena dapat menyelesaikan permasalahan konversi energi dan pengelolaan limbah secara bersamaan (Kim dkk., 2013; Zuliyana dkk., 2015; Bonanza dan Sarto, 2016; Nurkholis dkk., 2017).

Pada penelitian ini, limbah jeruk digunakan sebagai bahan utama produksi biohidrogen. Selain karena belum optimal dalam pengelolaan, limbah jeruk juga merupakan bahan yang murah dan mudah didapat. Jeruk tersusun dari struktur karbohidrat kompleks seperti selulosa, hemiselulosa dan komponen lain seperti protein, flavonoid dan minyak atsiri dengan komposisi seperti yang disajikan pada Tabel 1 .

Tabel 1. Komposisi limbah buah jeruk (Forgács, 2012)

\begin{tabular}{lc}
\hline \multicolumn{1}{c}{ Komponen } & Komposisi $\mathbf{( \% )}$ \\
\hline Abu & $2,5-5,1$ \\
Lemak & $0,44-4,00$ \\
Protein & $6,1-9,1$ \\
Flavonoid & $5,1-12,5$ \\
Minyak atsiri & $2-3$ \\
Karbohidrat: & \\
Gula & $6,0-22,9$ \\
Pektin & $12,1-25,0$ \\
Selulosa & $22,0-37,1$ \\
Hemiselulosa & $6,0-11,1$ \\
Lignin & $2,2-8,6$ \\
\hline
\end{tabular}

Tabel 1 menunjukkan bahwa buah jeruk banyak mengandung komponen karbohidrat, sehingga memiliki potensi untuk dikonversi menjadi biohidrogen. Namun, kandungan selulosa, hemiselulosa dan lignin pada buah dan kulit jeruk dapat membatasi peningkatan yield pada saat hidrolisis (Kapdan dan Kargi, 2006; Show dkk., 2012). Hal ini terjadi karena komponen lignoselulosa sulit untuk dihidrolisis oleh enzim hidrogenase. Selain itu, menurut Forgács (2012) komponen minyak atsiri yang tersusun atas $90 \%$ limonen juga bersifat anti mikroba, sehingga akan menghambat kinerja mikroorganisme ketika limbah jeruk digunakan sebagai substrat pada proses anaerob.

Dalam upaya untuk mereduksi kadar selulosa dan limonen di dalam buah jeruk, perlu dilakukan proses pretreatment substrat sebelum digunakan di dalam fermentasi anaerob. Mizuki dkk. (1990) telah berhasil mengurangi kandungan limonen pada jeruk dengan menggunakan metode steam distillation. Di samping itu, metode pretreatment tersebut juga dapat merusak struktur kompleks pada substrat yang mengandung lignoselulosa (Forgács 2012). Hal ini akan membuat lebih banyak substrat yang dikonversi menjadi hidrogen. Namun, sejauh ini belum ada penelitian yang mempelajari pengaruh dari steam pretreatment secara simultan terhadap dua komponen tersebut, yaitu limonen dan selulosa.

Produk dari penelitian ini adalah biohidrogen dengan tahapan proses pengasaman dan pengayaan terlebih dahulu untuk inokulum. Sementara itu, output-nya adalah untuk mengetahui pengaruh steam pretreatment terhadap produksi biohidrogen yang dihasilkan dari sampah buah jeruk. Parameter yang digunakan untuk mengamati kinerja mikroorganisme adalah $\mathrm{pH}$, total solid, volatile solid, volume hidrogen, kadar gas hidrogen, konsentrasi selulosa dan volatile fatty acid (VFA).

\section{Metode Penelitian}

\subsection{Bahan penelitian}

Bahan yang digunakan adalah sampah buah jeruk (bad stock), kultur mikroba campuran biodigester kotoran sapi, buah dan tahu, resazurin (Sigma Aldrich), gas nitrogen, dan alkohol. Selain itu, terdapat penggunaan bahan dari Merck di antaranya pepton, yeast extract granulated, $\mathrm{D}(+)-G l u k o s a$, L-cystein $\mathrm{HCl}, \mathrm{HCl}$ $37 \%, \mathrm{NaOH}$ pellet $99 \%, \mathrm{KH}_{2} \mathrm{PO}_{4} 99,5 \%$, $\mathrm{Na}_{2} \mathrm{HPO}_{4} 99 \%, \mathrm{MgSO}_{4} .7 \mathrm{H}_{2} \mathrm{O}, \mathrm{NaHCO}_{3}, \mathrm{KH}_{2} \mathrm{PO}_{4}$ $99,5 \%, \quad \mathrm{Na}_{2} \mathrm{HPO}_{4} \quad 99 \%, \quad \mathrm{MgSO}_{4} .7 \mathrm{H}_{2} \mathrm{O}, \quad$ dan $\mathrm{NaHCO}_{3}$. 


\subsection{Pretreatment}

Di dalam penelitian ini pretreatment dilakukan terhadap substrat limbah jeruk dan inokulum sebelum proses fermentasi. Pretreatment berupa steam distillation pada substrat jeruk bertujuan untuk mereduksi kandungan limonen dan selulosa dalam rangka mempercepat reaksi pada saat proses fermentasi. Sedangkan pada inokulum dibutuhkan pretreatment dengan menggunakan asam untuk mengeliminasi bakteri metanogen yang dapat mengonsumsi hidrogen.

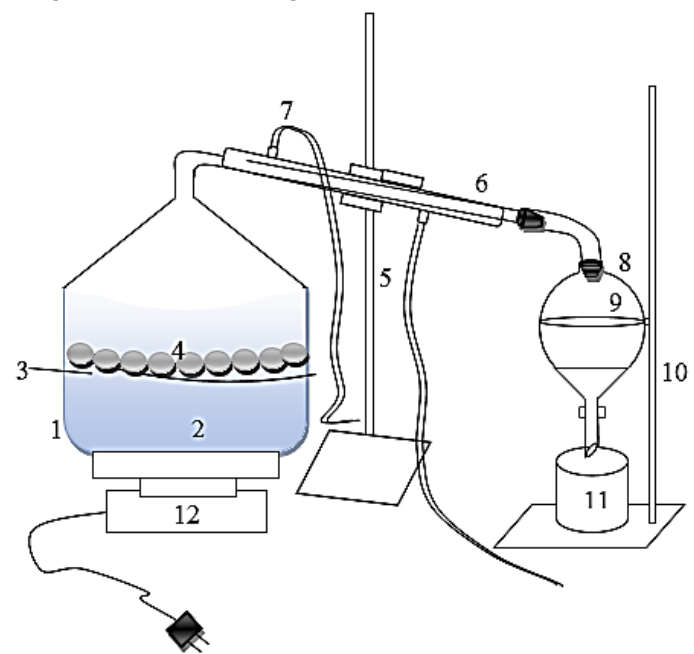

Keterangan:

1. Ketel distilasi

7. Selang air

2. Air kebutuhan steam

8. Adaptor

3. Angsang

4. Sampah buah jeruk

9. Corong pemisah

10. Statif

5. Statif

6. Pendingin balik

11. Gelas beaker

12. Hot plate

\section{Gambar 1. Skema alat distilasi uap}

Pretreatment terhadap substrat limbah buah jeruk dilakukan dengan mengaplikasikan steam distillation. Skema alat yang digunakan pada proses ini ditunjukkan pada Gambar 1. Komponen utama pada rangkaian alat proses distilasi ini adalah ketel, pendingin balik dan corong pemisah. Agar proses distilasi dapat berlangsung, ketel diisi dengan air hingga berada sedikit di bawah angsang. Kemudian sampel jeruk diletakkan di atas angsang sehingga tidak ada kontak langsung dengan air. Posisi sampel jeruk diatur sedemikian rupa agar uap dari bawah dapat tersebar secara merata. Setelah itu, tutup ketel direkatkan dengan lem sehingga tidak terjadi kebocoran uap. Pada komponen pendingin balik, terdapat 2 lubang untuk saluran air masuk dan keluar. Selang air dihubungkan dengan pompa agar terjadi sirkulasi air selama proses berlangsung. Hal ini dilakukan untuk menurunkan suhu uap dari ketel, sehingga uap dapat mengembun dan mengalir ke corong pisah. Setelah uap air terkondensasi masuk ke corong pemisah, maka akan terbentuk 2 lapisan yaitu air dan komponen minyak atsiri. Komponen tersebut perlu dipisahkan secara berkala. Proses steam distillation ini dilakukan dengan variasi waktu selama 2, 4 dan 6 jam.

Sementara itu, proses pretreatment pada inokulum dilakukan dengan pengasaman selama 24 jam. Inokulum yang digunakan pada penelitian ini berasal dari campuran kultur mikroba biodigester kotoran sapi, buah dan tahu. Sebelum dilakukan pencampuran, inokulum segar diasamkan dengan $\mathrm{HCl} 37 \%$ 2M hingga mencapai $\mathrm{pH}$ 3. Selanjutnya dilakukan pengadukan agar campuran menjadi homogen. Setelah 24 jam, diukur pH dari masing-masing inokulum. Sebelum inokulum digunakan, terlebih dahulu dilakukan penetralan $\mathrm{pH}$ dengan menambahkan $\mathrm{NaOH} 2 \mathrm{M}$.

\subsection{Pengayaan Inokulum dan Fermentasi}

Mikroorganisme yang telah terseleksi pada proses pretreatment kemudian diperkaya dengan penambahan nutrisi. Metode yang digunakan pada tahapan proses pengayaan inokulum mengacu pada metode yang telah diaplikasikan oleh Kharisma (2015). Larutan medium PYG (campuran pepton, yeast extract dan glukosa) digunakan untuk pengayaan inokulum. Pepton pada pembuatan medium berfungsi sebagai sumber nitrogen, yeast extract granulated sebagai sumber nitrogen, vitamin penyedia asamasam amino tunggal, dan growth factor, sementara $\mathrm{D}(+)$-Glukosa berperan sebagai sumber karbon. Pengayaan dilakukan sebanyak 3 kali hingga inokulum siap digunakan.

Setelah dilakukan pengayaan, maka inokulum dapat digunakan pada proses fermentasi. Proses ini dilakukan dengan menggunakan biodigester seperti yang dikembangkan oleh Stefani (2014). Biodigester ini menggunakan botol vial dengan kapasitas $100 \mathrm{~mL}$ yang diisi dengan inokulum 5 
$\mathrm{mL}$, substrat $15 \mathrm{~mL}$ dan nutrisi $30 \mathrm{~mL}$ untuk fermentasi. Skema biodigester ditunjukkan pada Gambar 2.

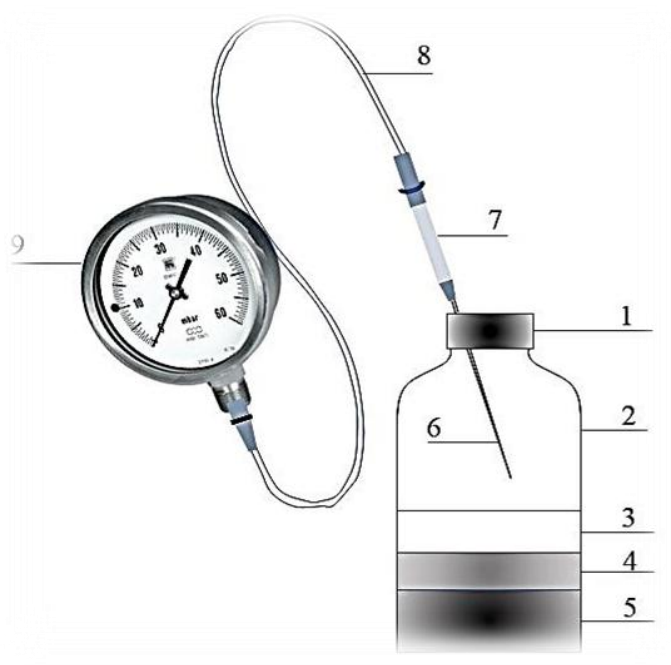

Keterangan:

1. Sumbat karet

6. Jarum

2. Headspace

7. Syringe

3. Nutrisi

8. Selang

4. Inokulum

9. Manometer

5. Substrat

Gambar 2. Skema biodigester (diadaptasi dari Stefani, 2014)

\section{Hasil dan Pembahasan}

\subsection{Kondisi Substrat}

Pretreatment yang telah dilakukan di dalam penelitian ini menggunakan steam distillation. Tujuan dari pretreatment tersebut adalah untuk mendegradasi limonen dan selulosa pada sampel buah jeruk. Proses pretreatment yang dilakukan pada substrat mengakibatkan terjadinya perubahan komposisi limbah jeruk, terutama selulosa dan limonen seperti yang ditunjukkan pada Gambar 3. Kadar awal selulosa dan limonen pada substrat adalah 37,10\% (Forgács, 2012) dan 211,77 ppm (Stefani, 2014). Pada substrat yang didistilasi selama 2, 4 dan 6 jam selulosa yang terukur berturut-turut adalah 37,08\%; 36,63\% dan $15,95 \%$. Nilai ini menunjukkan bahwa kadar selulosa dalam substrat semakin berkurang seiring dengan semakin lama waktu pretreatment. Kecenderungan yang sama terjadi pada konsentrasi limonen pada substrat. Limonen yang terukur pada distilasi substrat selama 2 jam menunjukkan nilai paling tinggi, yaitu 57,44 ppm.

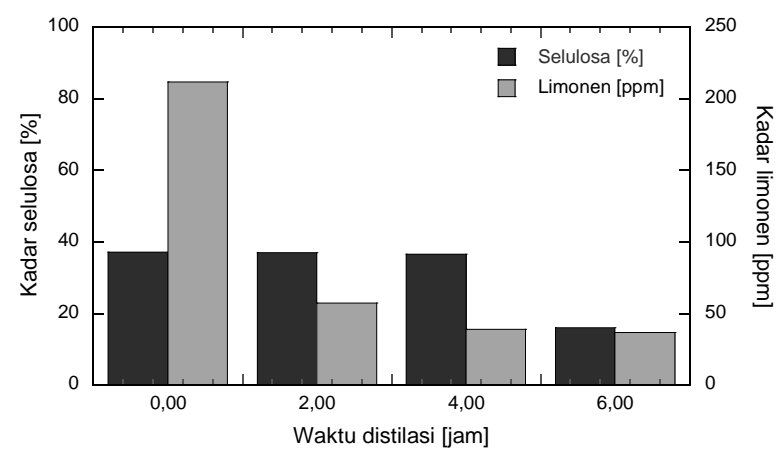

Gambar 3. Pengaruh pre-treatment terhadap kadar selulosa dan limonen

Hasil penelitian ini menunjukkan bahwa distilasi uap dapat digunakan untuk mengurangi kandungan limonen dan selulosa dalam substrat. Limonen menyusun $90 \%$ dari minyak atsiri yang terkandung pada jeruk (Forgács, 2012), sehingga pretreatment dengan distilasi uap dapat mengurangi limonen pada substrat melalui prinsip difusi (Mizuki, 1990). Sementara itu, terjadinya proses hidrolisis selulosa dapat dilihat dari pengurangan konsentrasi selulosa karena diuraikan menjadi gula sederhana kemudian dikonversi menjadi hidrogen melalui fermentasi.

\subsection{Produksi Hidrogen}

Variasi waktu steam pretreatment dilakukan untuk menganalisis pengaruhnya terhadap kandungan bahan. Sementara hidrogen yang diproduksi merupakan verifikasi dari efektivitas proses pretreatment yang dilakukan. Hubungan antara pretreatment dengan kuantitas dan kualitas hidrogen yang dihasilkan ditunjukkan pada Gambar 4 dan Gambar 5.

Gambar 4 menunjukkan bahwa volume akumulasi hidrogen meningkat seiring dengan bertambahnya waktu fermentasi. Produksi hidrogen paling banyak dihasilkan oleh sampel yang mendapat perlakuan pretreatment selama 4 jam setelah difermentasi selama 7 hari, yaitu $68,48 \mathrm{~mL}$. Sementara itu, sampel dengan pretreatment selama 2 jam menghasilkan hidrogen maksimum sebanyak $11,25 \mathrm{~mL}$ dan pada sampel dengan perlakuan 6 jam didapatkan produksi hidrogen maksimum dengan volume 
27,41 mL. Hal ini menunjukkan bahwa sampel dengan perlakuan pretreatment distilasi uap selama 4 jam lebih mudah untuk dikonsumsi mikroorganisme penghasil hidrogen.

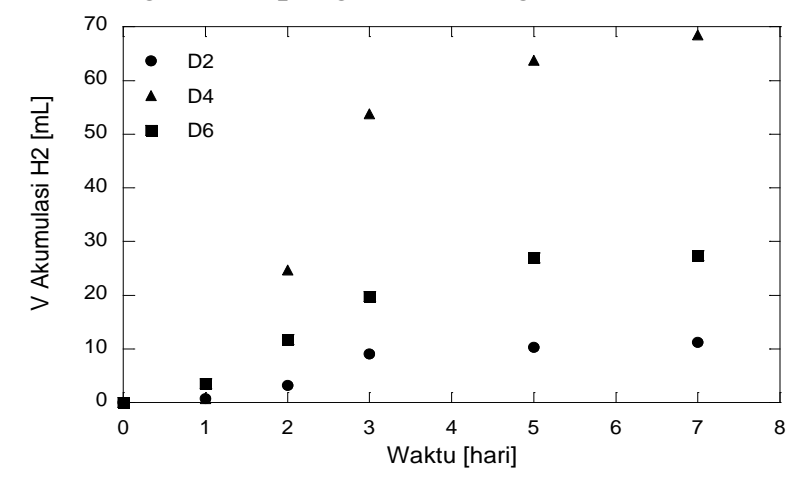

D2: Distilasi 2 jam

D4: Distilasi 4 jam

D6: Distilasi 6 jam

Gambar 4. Hubungan waktu dan volume akumulasi hydrogen

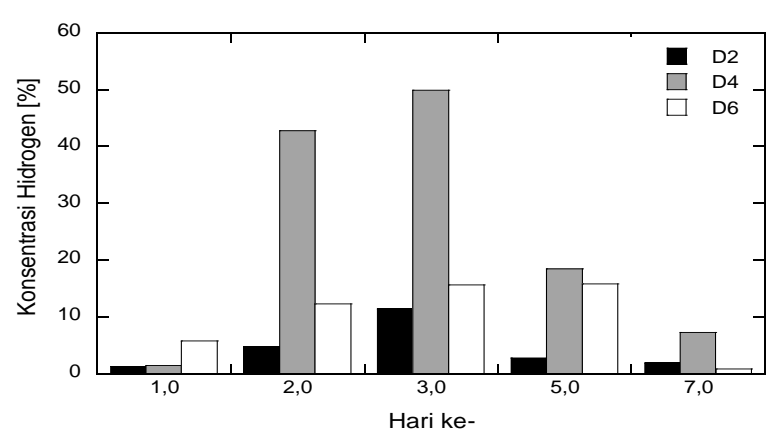

D2: Distilasi 2 jam

D4: Distilasi 4 jam

D6: Distilasi 6 jam

Gambar 5. Pengaruh pretreatment terhadap konsentrasi hydrogen

Gambar 5 menunjukkan bahwa konsentrasi hidrogen tertinggi diperoleh pada sampel D4 yaitu 49,9\% pada waktu fermentasi optimum. Peningkatan kadar hidrogen secara signifikan rata-rata terjadi setelah hari pertama. Hal ini menunjukkan bahwa setelah hari pertama, senyawa organik yang terkandung di dalam sampel lebih mudah difermentasi sehingga mikroorganisme menjadi lebih produktif.

Sampel D2 menghasilkan konsentrasi hidrogen paling rendah dalam pengujian ini. Rendahnya konsentrasi hidrogen dapat terjadi karena faktor substrat dan aktivitas mikroorganisme yang terlibat. Substrat yang masih dalam bentuk kompleks akan sulit dicerna oleh mikroorganisme, sehingga hanya sedikit yang akan dikonversi menjadi produk. Di samping itu, konsentrasi hidrogen yang rendah dapat pula diakibatkan karena aktivitas pertumbuhan mikroorganisme. Menurut Shuler dan Kargi (2002), terdapat beberapa fase pada pertumbuhan mikroorganisme di dalam sistem batch yaitu lag phase, exponential phase, deceleration growth, stationary dan death phase. Ketika diinokulasikan pada lingkungan baru, bakteri akan mengalami fase lag, atau dapat juga disebut dengan fase adaptasi. Dari Gambar 5 dapat dilihat bahwa fase lag pada pengujian ini berlangsung selama 1 hari.

Konsentrasi hidrogen pada sampel D6 tidak mengalami peningkatan yang signifikan setelah hari pertama. Hal ini dimungkinkan terjadinya produksi $\alpha$-terpineol dari limonen oleh mikroorganisme di dalam digester. Dari penelitian Ruiz dan Flotats (2014), bakteri anaerobik dapat mentransformasi limonen menjadi $\alpha$-terpineol yang mempunyai minimum inhibitory concentration lebih tinggi, yaitu $0,450-0,9 \mu \mathrm{L} / \mathrm{mL}$ sedangkan limonen $0,6-5$ $\mathrm{mg} / \mathrm{mL}$. Selain itu, kemungkinan lain adalah terjadinya hidrolisis lanjut glukosa menjadi senyawa furfural. Furfural merupakan senyawa yang dapat berperan sebagai inhibitor dalam proses hidrolisis dan dapat diproduksi dari bahan yang mengandung banyak pentosane (Taherzadeh dan Niklasson, 2003). Furfural dan turunannya dapat berdampak terhadap pertumbuhan mikroorganisme dengan mempengaruhi enzim glikolitik dan atau enzim fermentasi. Keberadaan furfural sebanyak 1g/L sudah dapat memberikan dampak inhibisi di dalam sistem (Quéméneur, 2012). Quéméneur menganalisis dampak dari $1 \mathrm{~g} / \mathrm{L}$ furfural dan HMF pada produksi hidrogen dari xylosa (salah satu komponen dari lignoselulosa) dengan konsentrasi $5 \mathrm{~g} / \mathrm{L}$. Penelitian tersebut dilakukan dengan fermentasi anaerobik. Hasil yang didapatkan adalah terjadinya penurunan yield hidrogen sebanyak $1,22 \mathrm{~mol} \mathrm{H}_{2} / \mathrm{mol}$ xylosa dan tidak terbentuknya gas setelah dilakukan penambahan furfural dan HMF. 
3.3 Pengaruh Fermentasi terhadap Volatile Solid dan Volume Akumulasi Hidrogen

Pengaruh fermentasi terhadap volatile solid (VS) dan akumulasi hidrogen ditunjukkan oleh Gambar 6. Pada hari pertama VS berada pada konsentrasi paling tinggi. Setelah itu VS berkurang drastis kemudian konstan hingga akhir. Berkurangnya konsentrasi VS menunjukkan mikroorganisme telah mendegradasi senyawa organik di dalam digester. Sementara itu, nilai VS yang konstan menunjukkan hanya sedikit substrat yang dikonsumsi oleh mikroorganisme. Hal ini dapat terjadi dikarenakan beberapa kemungkinan, yaitu mikroorganisme sudah memasuki fase kematian atau terdapat racun yang membuat mikroorganisme mati lebih cepat.

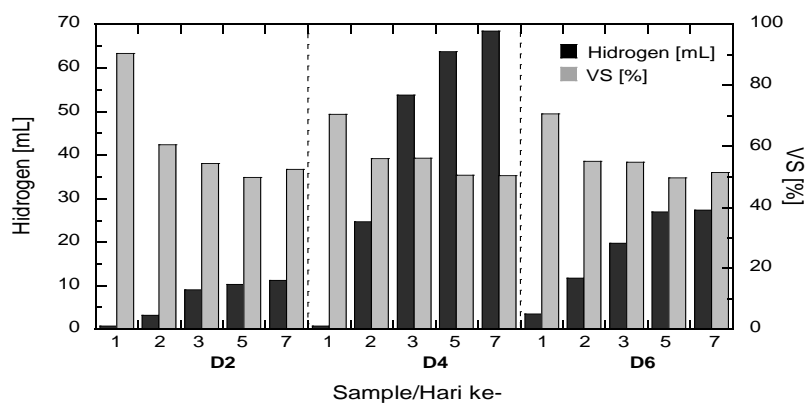

D2: Distilasi 2 jam

D4: Distilasi 4 jam D6: Distilasi 6 jam

Gambar 6. Pengaruh fermentasi terhadap volatile solid dan volume akumulasi hidrogen

Konsentrasi VS dapat berpengaruh terhadap hidrogen yang terbentuk. Kecenderungan yang ditunjukkan oleh VS yaitu semakin menurun seiring bertambahnya waktu fermentasi. Berlawanan dengan VS, volume hidrogen yang dihasilkan semakin bertambah. Pada sampel kontrol, akumulasi hidrogen mencapai $84,21 \mathrm{~mL}$ seiring dengan penurunan VS sebanyak $45,5 \%$. Sampel D2 menghasilkan volume hidrogen sebanyak $11,25 \mathrm{~mL}$ saat VS mencapai $52,39 \%$. Penurunan VS pada sampel D2 mencapai 38\%. Pada sampel yang di-pretreatment selama 4 jam, hidrogen yang diproduksi adalah sebanyak 68,48 $\mathrm{mL}$. Sementara pada sampel D6, akumulasi hidrogen hanya mencapai $27,41 \mathrm{~mL}$. Data ini menunjukkan bahwa perlakuan pretreatment steam distillation pada jeruk mencapai nilai paling efektif prosesnya dilakukan selama 4 jam.

\subsection{Profil Distribusi VFA}

Di dalam penelitian ini, profil distribusi volatile fatty acid (VFA) dapat dilihat pada Gambar 7. Komponen asetat dan butirat berpengaruh terhadap konsentrasi hidrogen. Hidrogen meningkat seiring dengan peningkatan konsentrasi asetat dan butirat. Asetat dan butirat merupakan komponen VFA utama di dalam produksi hidrogen (Kim dkk., 2013). Sementara, keberadaan asam propionat di dalam digester akan menyebabkan konsentrasi hidrogen menurun. Propionat total yang terdapat di dalam digester $\mathrm{C}$ selama 7 hari adalah $3,4 \%$ dari total VFA; D2 10,8\%; D4 0,6\%; dan D6 54,9\%. Propionat paling banyak terbentuk pada digester D6. Hal ini membuktikan bahwa keberadaan propionat dalam jumlah banyak mengindikasikan sedikitnya hidrogen yang dihasilkan (Kim, 2013).

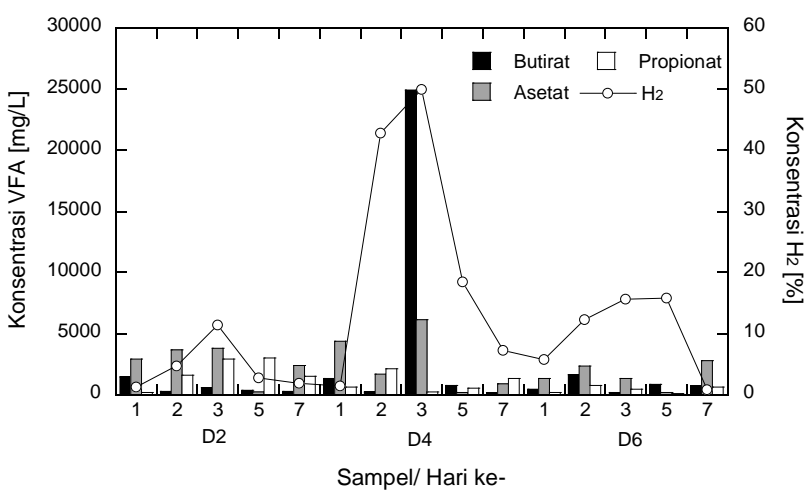

D2: Distilasi 2 jam

D4: Distilasi 4 jam

D6: Distilasi 6 jam

Gambar 7. Profil distribusi VFA terhadap konsentrasi hidrogen

Jumlah VFA yang terbentuk dapat memberikan dampak terhadap $\mathrm{pH}$ medium, sehingga dapat mempengaruhi aktivitas mikroorganisme dalam memproduksi hidrogen.

\subsection{Model Laju Produksi Biohidrogen}

Parameter yang dianalisis di dalam penelitian ini adalah volume dan kadar hidrogen, kadar volatile fatty acid (VFA), kadar selulosa dan limonen. Pengambilan sampel dilakukan pada hari ke 1, 2, 3, 5 dan 7. Setelah itu analisis 
kuantitatif dilakukan dengan menggunakan

Persamaan Gompertz termodifikasi untuk menghitung nilai $R_{m}, H_{\text {maks }}$ dan $\lambda$, seperti di tunjukkan oleh persamaan (1) (Cui dkk., 2010).

$H(t)=H_{\text {maks }} \exp \left\{-\exp \left[\frac{R_{m} e}{H_{\text {maks }}}(\lambda-t)+1\right]\right\}$

dengan :

$$
\begin{aligned}
H(t)= & \text { volume biohidrogen kumulatif }(\mathrm{mL}) \\
H_{\text {maks }}= & \text { potensi produksi biohidrogen }(\mathrm{mL}) \\
R_{m}= & \text { laju maksimum produksi biohidrogen } \\
& (\mathrm{mL} / \mathrm{jam}) \\
e \quad= & 2.71828 \text { (bilangan Euler) } \\
\lambda \quad & \text { lag phase, waktu minimum produksi } \\
& \text { biohidrogen (jam) } \\
= & \text { waktu produksi (jam) }
\end{aligned}
$$

Dari hasil analisis model laju produksi, diperoleh nilai konstanta kinetika $R_{m}, H_{\text {maks }}$ dan $\lambda$, seperti disajikan pada Tabel 2.

Dari Tabel 2, potensi produksi hidrogen paling tinggi ditunjukkan oleh sampel D4 sebanyak 52,612 mL. Sementara sampel D2 mempunyai potensi produksi paling rendah, yaitu 11,492 mL. Konstanta potensi produksi hidrogen $\left(H_{\text {maks }}\right)$ pada parameter Gompertz menunjukkan kecenderungan yang sama dengan data yang didapat pada saat pengamatan. Data pengamatan volume akumulasi pada sampel D4 dan D6 mencapai nilai yang lebih tinggi daripada nilai $H_{\text {maks }}$.

Parameter Gompertz lainnya yang diperoleh adalah konstanta laju produksi maksimum $\left(R_{m}\right)$. Konstanta pada sampel D6 adalah nilai yang paling tinggi, yaitu $12,982 \mathrm{~mL}$ hidrogen/jam. Nilai $R_{m}$ yang tinggi disebabkan banyaknya kandungan bahan organik yang terdapat di dalam digester. Hal ini dikarenakan proses pretreatment yang lama membuat lignoselulosa lebih banyak terurai. Namun, pada sampel D6 produksi hidrogen hanya sedikit. Hal ini dimungkinkan hemiselulosa juga banyak yang diuraikan menjadi pentosan, yang merupakan bahan yang paling berpotensi dihidrolisis lanjut menjadi furfural dan turunannya. Komponen furfural merupakan inhibitor di dalam proses fermentasi anaerobik (Quéméneur, 2012). Sementara itu, laju produksi hidrogen pada sampel D2 rendah karena adanya limonen dengan kandungan yang masih tinggi yaitu 59,91 ppm dan masih terdapat selulosa sebanyak 37,1\%. Hal ini juga mempengaruhi mikroorganisme pada digester yang diberi perlakuan steam distillation 2 jam sehingga waktu adaptasi (lag phase) menjadi paling lama, yaitu 49,689 jam.

\section{Kesimpulan}

Pengaruh pretreatment berupa steam distillation terhadap kandungan selulosa dan limonen pada substrat buah jeruk dan dampaknya terhadap produksi hidrogen telah dievaluasi. Steam distillation yang dilakukan untuk pretreatment pada substrat jeruk berpengaruh signifikan terhadap kondisi substrat, yaitu mengurangi kadar selulosa dan limonen. Setelah pretreatment, kadar selulosa yang terukur setelah 2, 4 dan 6 jam berturut-turut adalah 37,08\%; $36,63 \%$ dan $15,95 \%$. Sementara itu, kadar limonen setelah pretreatment 2, 4 dan 6 jam menunjukkan nilai 57,44 ppm; $38,80 \mathrm{ppm}$; dan $36,11 \mathrm{ppm}$.

Produksi hidrogen paling banyak dihasilkan oleh sampel yang mendapat perlakuan pretreatment selama 4 jam, yaitu $68,48 \mathrm{~mL}$. Sementara itu, sampel dengan pretreatment selama 2 jam menghasilkan hidrogen sebanyak $11,25 \mathrm{~mL}$ dan pada sampel dengan perlakuan 6 jam didapatkan hidrogen dengan volume 27,41 $\mathrm{mL}$.

Tabel 2. Parameter produksi hidrogen dengan persamaan Gompertz termodifikasi

\begin{tabular}{|c|c|c|c|c|c|}
\hline \multirow{2}{*}{ Sampel } & \multirow{2}{*}{$\begin{array}{c}\text { Waktu } \\
\text { Pretreatment } \\
\text { (jam) }\end{array}$} & \multicolumn{2}{|c|}{ Parameter Persamaan Gompertz } & \multirow{2}{*}{ RSS } \\
\cline { 3 - 5 } & $\begin{array}{c}H_{\text {maks }} \\
\left(\mathrm{mL} \mathrm{H}_{2}\right)\end{array}$ & $\begin{array}{c}R_{m} \\
\left(\mathrm{~mL} \mathrm{H}_{2} / \mathrm{jam}\right)\end{array}$ & $\lambda(\mathrm{jam})$ & \\
\hline D2 & 2 & 11,492 & 9,888 & 49,689 & $2,621 \times 10^{-10}$ \\
D4 & 4 & 52,612 & 10,008 & 24,742 & $5,684 \times 10^{-9}$ \\
D6 & 6 & 22,345 & 12,982 & 24,885 & $1,048 \times 10^{-7}$ \\
\hline
\end{tabular}


Dari segi kualitas, konsentrasi hidrogen tertinggi juga diperoleh pada sampel D4 yaitu 49,9\% pada waktu fermentasi optimum, yaitu 3 hari. Hal ini menunjukkan bahwa perlakuan pretreatment distilasi uap selama 4 jam (D4) merupakan kondisi optimum untuk proses hidrolisis substak menjadi hidrogen.

\section{Ucapan Terimakasih}

Penulis mengucapkan terimakasih kepada Bakrie Graduate Fellowship atas bantuan finansial selama studi.

\section{Daftar Pustaka}

Bonanza, B. S. W. dan Sarto, 2016, Pengaruh variasi organic loading rate sampah buah jeruk terhadap produksi biohidrogen pada reaktor kontinu, Jurnal Rekayasa Proses, Vol. 10 No.2, 43-46.

Cui, M., Yuan, Z., Zhi, X., Wei, L., Shen, J., 2010, Biohydrogen production from poplar leaves pretreated by different methods using anaerobic mixed bacteria, Int. J. Hydrogen Energy, 35, 4041-4047.

Han, H., Wei, L., Liu, B., Yang, H., Shen, J., 2012, Optimization of biohydrogen production from soybean straw using anaerobic mixed bacteria, Int. J. Hydrogen Energy, 37, 13200-13208.

Forgács, G., 2012, Biogas production from citrus wastes and chicken feather: pretreatment and co-digestion, Disertasi, Chalmers University of Technology.

Kapdan, I. K., dan Kargi, F., 2006, Bio-hydrogen production from waste materials, Enzyme and Microbial Technology, 38, 569-82.

Kharisma, A. D., 2015, Pengaruh hidrogen peroksida terhadap produksi hidrogen dari limbah buah melon (Cucumis melo L.) oleh mikroba digester biogas, Tesis, Universitas Gadjah Mada.

Kim, MS., Cha, J., Kim, DH., 2013, Fermentative biohydrogen production from solid wastes, Biohydrogen, 11, 259-283.
Kumar, N., dan Das, D., 2000, Enhancement of hydrogen production by Enterobacter cloacae IIT-BT 08c, Process Biochemistry, 35, 58993.

Mizuki, E., Akao, T., Saruwatari, T., 1990, Inhibitory effect of citrus unshu peel on anaerobic digestion, Biological Wastes, 33, 161-68.

Nurkholis, Sarto, Hidayat, M., 2017, Pengaruh organic loading rate pada produksi biohidrogen dari sampah buah melon (Cucumis melo L.) menggunakan reaktor alir pipa, Jurnal Rekayasa Proses, Vol.11. No.1, 12-18.

Quéméneur, M., Hamelin, J., Barakat, A., Steyer, J.-P., Carrère, H., Trably, E., 2012, Inhibition of fermentative hydrogen production by lignocellulosic-derived compounds in mixed cultures, Int. J. Hydrogen Energy, 37(4):31509.

Ruiz, B. dan Flotats, X., 2014, Citrus essential oils and their influence on the anaerobic digestion process: An overview, Waste Management, 34(11), 2063-2079.

Show, K. Y., Lee, D. J., Tay, J. H., Lin, C. Y., Chang, J. S., 2012, Biohydrogen production: current perspectives and the way forward, Int. J. Hydrogen Energy, 37, 15616-31.

Shuler, M. L. dan Kargi, F., 1992, Bioprocess Engineering. Prentice Hall, Englewood Cliffs, New Chemical Engineering Department, Kasetsart University, Bangkok.

Stefani, W., 2014, Produksi biogas dari campuran sampah buah dengan perlakuan awal distilasi uap, Igarss, 1-5.

Taherzadeh, M. J., dan Niklasson, C., 2003, Ethanol from lignocellulosic materials: pretreatment, acid and enzymatic hydrolysis and fermentation, Prentice-Hall International, Inc., New Jersey, 3 ed., pp. 6-9.

Zuliyana, Kompiang, S. K., Budhijanto, W., Cahyono, R. B., 2015, Pengaruh kadar air umpan dan rasio $\mathrm{c} / \mathrm{n}$ pada produksi biogas dari sampah organik pasar, Jurnal Rekayasa Proses, Vol. 9 No. 1, 22-27. 